\title{
Brief counseling by pharmacists enhances the knowledge, perceptions, and compliance of first and second-trimester pregnant women consuming ferrous fumarate at Jetis Community Health Center of Yogyakarta
}

\author{
Nurul Kusumawardani ${ }^{1,2}$, Endang Darmawan*1, Akrom ${ }^{1}$, Sulistiari Retnowati ${ }^{3}$ \\ ${ }^{1}$ Postgraduate Program on Clinical Pharmacy, Faculty of Pharmacy \\ Universitas Ahmad Dahlan, Yogyakarta \\ ${ }^{2}$ Pharmacy Study Program, Universitas Alma Ata \\ ${ }^{3}$ PKU Muhammadiyah Hospital, Yogyakarta
}

\begin{abstract}
In Indonesia, the prevalence of anemia during pregnancy increased from $37.1 \%$ in 2013 to $48.9 \%$ in 2018. It plays a significant part in elevated maternal mortality and perinatal rates. This research aimed to determine the influence of a brief counseling intervention by pharmacists based on the ' $5 \mathrm{~A}$ ' strategy that had been modified to include the knowledge, perceptions, and compliance of pregnant women with the recommended consumption of ferrous fumarate as anemia treatment and prevention. It is a quasi-experimental study with a pretest-posttest control group design. The data were collected prospectively from December 2018 to February 2019. The sample consisted of 26 respondents, divided into a control group and an intervention group. Each group comprised 13 pregnant women in their first and second trimester (ranging from 12 to 27 weeks). The knowledge, perceptions, and compliance in each group were measured on the first day of visit (Day 1; pretest) and Day 31 (posttest) after the intervention. The results showed a significant difference in average scores between the pretest and posttest in the intervention group ( $p<0.001$ for knowledge, perceptions, and compliance parameters) but an insignificant difference in the control group ( $p=0.185, p=0.366$, and $\mathrm{p}=0.111$, respectively). Score difference or improvement was determined from the relative risk (RR) values of the three parameters $(4.55,4.54$, and 10.29 , respectively, with $\mathrm{p}<0.50)$. As a conclusion, a brief counseling intervention based on the modified ' $5 \mathrm{~A}$ ' strategy can enhance the knowledge, perceptions, and compliance of first and second-trimester pregnant women at Jetis Community Health Center with the proper consumption of Fe fumarate as an iron supplement.
\end{abstract}

Keywords: compliance, counseling, fe fumarate, knowledge, perceptions, pregnant women

\footnotetext{
*Corresponding Author:

Endang Darmawan

Pharmacy Postgraduate, Faculty of Pharmacy

Universitas Ahmad Dahlan, Yogyakarta

Email: endang.darmawan@pharm.uad.ac.id
} 


\section{INTRODUCTION}

Anemia during pregnancy occurs if the examined hemoglobin $(\mathrm{Hb})$ count is $\langle 11 \mathrm{~g} / \mathrm{dL}$, followed by symptoms like fatigue, tingling and numbness, decreased appetite, headache, and pale face. Iron deficiency anemia during pregnancy is currently a global health issue, which, in the case of Indonesia, is indicated by the increased rate of anemia during pregnancy in 2013-2018 (from 37.1\% to 48.9\%) (Kemenkes, 2018). This condition has been reported as a strong determinant in the elevated prevalence of low birth weight and risk of maternal and perinatal mortalities (WHO, 2011; Adam, 2016).

The increased prevalence of anemia in pregnant women is attributable to lack of compliance with the recommended consumption of iron supplements during pregnancy. Drug side effects become one of the causative factors. The most common drug side effects include gastrointestinal disorders like nausea, vomiting, and constipation (Vernissa et al., 2017). The same case of low compliance among pregnant women has been reported in the Philippines (Lutsey et al., 2008), Nigeria (Oriji et al., 2011), and Malaysia (Thirukkanesh and Zahara, 2010). The reluctance of pregnant women to continue consuming iron supplements is believed to be the result of their insufficient knowledge about the significance of iron supplements and proper ways to overcome the drug side effects.

The Indonesian government has implemented attempts to prevent and overcome anemia by recommending the consumption of at least ninety pills of iron supplements containing ferrous $(\mathrm{Fe})$ fumarate or $\mathrm{Fe}$ sulfate during pregnancy (Kemenkes, 2014). Fe fumarate is more effective in increasing $\mathrm{Hb}$ count, and it has a lower effect compared with the administration of Fe sulfate for 30-90 days in anemic pregnant women (Santiago, 2012; Singhal et al., 2015; Rezk et al., 2015). Fe fumarate is also useful in elevating serum ferritin levels than Fe bisglycinate and carbonyl iron (Patil et al., 2013). Besides, Fe fumarate is a free supplement provided by the government through the Social Security Administrator for Health (BPJS) and is regularly given to pregnant women at any community health center. The government's attempt to reduce the prevalence of anemia during pregnancy needs to be supported by sufficient knowledge and compliance of pregnant women with its treatment and prevention measures, i.e., routine consumption of iron supplements. Therefore, the role of pharmacists is required to overcome this problem (Endang and Fourianalisyawati, 2012; Anggreni, 2008).

Brief counseling intervention based on the ' $5 \mathrm{~A}$ ' method, referred to as brief counseling-5A, has been reported as an effective short-term therapy to enhance patient medication compliance (Mulianti et al., 2014; Akrom and Nurwijayanti, 2015; Saputri et al., 2017; Heryadi et al., 2017). It facilitates pharmacists in understanding the readiness of each respondent to change their behaviors toward the appropriate consumption of iron supplements (Whitlock et al., 2002).

There has been no experimental study on brief counseling-5A strategy for pregnant women at Jetis Community Health Center of Yogyakarta to date, particularly related to anemia and the proper administration of Fe fumarate supplements during pregnancy as well as its side effects management, advantages, and disadvantages. The influence of such intervention was determined through the assessment of knowledge, perceptions, and compliance using a set of questionnaires in pretest and posttest, with a time lag of 30 days. This time lag is based on the efficacy of communicators in delivering the message to trigger a change in patient behavior (Azwar, 2012). The peak time at which respondents change their behavior and enact the provided information is five days after the intervention, and it reduces significantly within 30 days (Bookhart et al., 2007; Bosworth et al., 2011). This study was designed to determine the effects of the brief counseling-5A intervention on the knowledge, perceptions, and compliance of pregnant women with the suggested consumption of $\mathrm{Fe}$ fumarate at Jetis Community Health Center of Yogyakarta.

\section{RESEARCH METHOD Data}

The respondents in this study were pregnant women in their first and second trimester $(\leq 27$ weeks) who consumed Fe fumarate and went to a regular checkup at Jetis Community Health Center of Yogyakarta. A sample size of 26 respondents was determined using the Slovin's formula and an 
additional of $15 \%$ to avoid loss to follow-up (LTFU). The research instruments included the brief counseling-5 A module and questionnaires of knowledge, perceptions, and compliance. The module incorporates five phases, namely to assess (i.e., assessing respondents' confidence, habit, and knowledge of their current medication conditions), to advise (educating respondents on the advantages and disadvantages of behavior change), to agree (respondent-counselor collaboration about planning for behavior change in respondent's medication), to assist (identifying personal obstacles in drug use and their management, as well as family support), and to arrange (planning an evaluation or follow-up of actualized behavior change) (Glasgow et al., 2002; Whitlock et al., 2002). Behavior change in this study refers to the consumption of Fe fumarate as an anemia therapy or prevention during pregnancy. In the pretest and posttest survey, the distributed questionnaires consist of close-ended questions and three domains, namely disease or knowledge of anemia during pregnancy, intervention, and general health that is associated with nutrition and drug side effects. They were designed to measure the level of knowledge, perceptions, and compliance, each containing ten questionnaire items.

Based on the questionnaire validity and reliability tests, each item of the questionnaires was considered valid and reliable. In the reliability test, the Cronbach's alpha values of knowledge, perceptions, and compliance items were $0.816,0.638$, and 0.782 . A questionnaire can be divided into four classes of reliability based on the Cronbach's alpha, namely low-stakes $(0.7 \leq \alpha<0.9)$, acceptable $(0.6 \leq \alpha<0.7)$, low $(0.5 \leq \alpha<0.6)$, and unacceptable $(\alpha<0.5)$. Hence, the questionnaire used in this study was deemed reliable and acceptable. The informed consent form and research protocol have been reviewed and approved by the Ethics Committee of Health Research of the Regional Public Hospital "Dr. Moewardi", Faculty of Medicine, Sebelas Maret University, Surakarta (No. 426/IV/HREC/2018).

\section{Research Procedure}

Prospective respondents who met the inclusion criteria were approached by the research team members and inquired regarding their willingness to participate in the study. After filling out the informed consent form, the willing participants were interviewed by the team to complete their sociodemographic and questionnaire data. Then, the respondents in the intervention group partook in brief counseling-5A, while the ones in the control group received medication information according to the practiced procedure at Jetis Community Health Center of Yogyakarta. Thirty days after the first visit (pretest) or on Day 31, a posttest was carried out by reassessing the level of respondents' knowledge, perceptions, and compliance.

\section{Data Analysis}

To prove the hypothesis, the researchers analyzed the data in statistical product and service solutions (SPSS) program. Chi-square test was used to describe the distribution of frequency and proportion of socio-demographic respondents in the control and intervention groups with categorical data. Also, a comparative analysis of paired numerical data was employed to identify the difference in mean score between the pretest and posttest questionnaire: t-test for normally distributed data or Wilcoxon for data with no normal distribution. Variations in the mean score of pretest and posttest and the score difference $(\Delta)$ of knowledge, perceptions, and compliance between the control and intervention groups were analyzed with an independent t-test for normally distributed data or MannWhitney $\mathrm{U}$ for data with no normal distribution. The relative risk (RR) analysis was used in this experimental research design to determine the association of exposure (i.e., brief counseling-5A) with the level of knowledge, perceptions, and compliance.

\section{RESULTS AND DISCUSSION}

\section{Socio-demographic Characteristics}

The socio-demographic characteristics of the control and intervention groups are shown in Table I. They comprise age during pregnancy, educational background, and occupation. The Chisquare test results showed that there was no significant difference between the control and intervention groups ( $p>0.050)$. It signifies no variation in the proportion of respondents in each group by socio- 
demographic characteristics. Based on the univariate analysis, the majority of the respondents are in the age range of 20-40 years. According to the Ministry of Health of the Republic of Indonesia, this age range does not belong to the preconditions of high-risk pregnancy, and it instead shows physical and mental readiness for pregnancy and childbirth (Kemenkes, 2012). Meanwhile, pregnancy at a young age (under 20 years old) is associated with high-risk pregnancy that contributes to high neonatal, infant, and toddler mortality, risk factors for anemia, and postpartum hemorrhage.

Table I. The socio-demographic characteristics of sampled pregnant women in their first and second trimester who consume Fe fumarate at Jetis Community Health Center, Yogyakarta Socio-demographic
Characteristics Frequency of first- and second-trimester p-value respondents (n, \%)

\begin{tabular}{lrrr}
\hline Age during pregnancy & & & \\
$\quad$ At risk (<20 years old) & $6(46)$ & $4(31)$ & $0.420^{\mathrm{a}}$ \\
$\quad$ Not at risk (20-40 years old) & $7(54)$ & $9(69)$ & \\
$\begin{array}{l}\text { Educational attainment } \\
\text { Primary (SD-SMP) }\end{array}$ & $1(8)$ & $1(8)$ & \\
$\begin{array}{l}\text { Advanced (SMA-Sarjana) } \\
\text { Occupation } \\
\text { In private sectors }\end{array}$ & $12(92)$ & $12(92)$ & $1,000^{\mathrm{b}}$ \\
$\quad$ & $4(31)$ & $7(54)$ & \\
Homemakers & $9(69)$ & $6(46)$ & $0.230^{\mathrm{a}}$ \\
\hline Pearson Chi-square ${ }^{\mathrm{b}}$ Fisher's exact test & & &
\end{tabular}

Based on education, almost all respondents have completed senior high school (SMA), i.e., 92\% each in the control and intervention groups. Formal education degree attained by pregnant women determines their compliance with the proper administration of iron supplements (Heryadi et al., 2017). The level of education, as well as occupation, differentiates individuals in accepting and understanding the given information (Layqah, 2018). The equal socio-demographic proportions in this study are expected to play no role in modifying the results of brief counseling-5A on the level of knowledge, perceptions, and compliance of pregnant women.

\section{The level of knowledge, perceptions, and compliance}

On the first day of visit (pretest), the initial conditions of knowledge, perceptions, and compliance before the implementation of brief counseling-5A were assessed. The results are presented in Table II. The mean score of knowledge and compliance during the pretest was statistically analyzed with a parametric independent sample test for groups of data with normal distribution, and the Levene's test showed a homogeneous result ( $p>0.050)$. 
Table II. The mean scores of the level of knowledge, perceptions, and compliance of pretest respondents with first- and second-trimester pregnancies who consume Fe fumarate at Jetis Community Health Center, Yogyakarta

\begin{tabular}{lrrr}
\hline \multirow{2}{*}{$\begin{array}{c}\text { Dependent } \\
\text { Variables }\end{array}$} & \multicolumn{2}{c}{ The average scores of the research groups $(\overline{\boldsymbol{X}} \pm \mathbf{S E})$} & p-value pretest \\
\cline { 2 - 3 } & Control $(\mathbf{n = 1 3})$ & Intervention $(\mathbf{n}=\mathbf{1 3})$ & \\
\hline Knowledge & $50.77 \pm 3.66$ & $57.69 \pm 5.08$ & $0.280^{\mathrm{a}}$ \\
Perceptions & $26.62 \pm 0,77$ & $26.46 \pm 1.20$ & $1.000^{\mathrm{b}}$ \\
Compliance & $43.85 \pm 4.32$ & $46.15 \pm 4.60$ & $0.718^{\mathrm{a}}$ \\
\hline
\end{tabular}

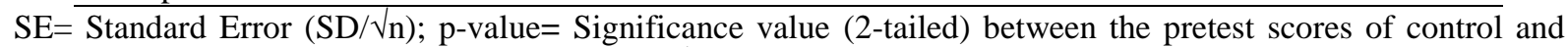
intervention groups; ${ }^{\mathrm{a}}=$ Independent sample test; ${ }^{\mathrm{b}}=$ Mann-Whitney test

The results showed that the mean pretest scores of knowledge and compliance between the control and intervention groups did not differ significantly $(\mathrm{p}=0.280$ and $\mathrm{p}=0.718$ ) (Table II). As for the level of perceptions, the mean scores were subjected to Mann-Whitney test because they were not normally distributed after the transformation process $(\mathrm{p}<0.050)$ and had the same or homogeneous variance $(p>0.050)$. The analysis showed that there was no significant difference between the pretest results of the control and intervention groups $(\mathrm{p}=1.000)$.

Based on the results of the pretest analysis of all respondents in the control and intervention groups, the respondents' level of knowledge was moderate (mean score $=50-75 \%$ ), mostly with negative perceptions of anemia and the consumption of iron supplements (mean score<30) and low compliance with recommended Fe fumarate intake during pregnancy (mean score $=0-49 \%$ ). The parametric and non-parametric independent sample tests revealed that the data did not have a significant statistical difference. Afterward, these results were used to determine any changes in the level of knowledge, perceptions, and compliance. In the intervention group, changes were apparent after receiving brief counseling with modified 5A model.

\section{The effects of brief counseling-5A on the level of knowledge}

The extent to which an individual comprehends a condition or disease and its treatment is one of the predisposing factors in achieving therapeutic goals (Bloom, 1956; Adam, 2015). Brief counseling$5 \mathrm{~A}$ is designed to, among others, increase respondents' knowledge of anemia and iron supplements intake, especially ferrous fumarate, during pregnancy. Table III explains any changes in the pre- and posttest scores after intervention by pharmacists, which are denoted by $\Delta$ score. The statistical analysis of $\Delta$ score in the intervention and control groups used the non-parametric Mann-Whitney test because the data in one of them was not normally distributed ( $\mathrm{p}=0.637$ for the former and $\mathrm{p}=0.030$ for the latter). Also, to obtain the $\Delta$ score of level of knowledge, the researchers employed a comparative analysis of the pretest and posttest scores in each study group (Figure 1), i.e., the Mann-Whitney test, because these scores were not normally distributed $(\mathrm{p}<0.050)$.

Table III. The $\Delta$ score of level of knowledge of respondents in their first- and second-trimester pregnancies who consume $\mathrm{Fe}$ fumarate at Jetis Community Health Center, Yogyakarta City before and after receiving brief counseling-5A

\begin{tabular}{lrc}
\multicolumn{1}{c}{ Groups } & \multicolumn{1}{c}{$\Delta \pm \mathrm{SE}$} & $\boldsymbol{p}$-value between research groups \\
\hline Control $(\mathrm{n}=13)$ & $3.08 \pm 3.65$ & $0.000^{*}$ \\
Intervention & $30.00 \pm 6.50$ & \\
$(\mathrm{n}=13)$ & & \\
\hline
\end{tabular}

$\mathrm{SE}=$ Standard Error $(\mathrm{SD} / \sqrt{\mathrm{n}}) ;{ }^{*}=$ the Mann-Whitney $\mathrm{U}$ test produces significant difference $(p<0.050)$ in the mean $\Delta$ score between the control and intervention group 
Table III presents an increase $(\Delta)$ from the pretest to the posttest scores in the two groups of respondents. The Wilcoxon test results (with a 95\% confidence interval) in the intervention group indicated a significant $\Delta$ score $(\mathrm{p}=0.000)$. In contrast, the mean scores of the pretest and posttest in the control group had no significant difference $(\mathrm{p}=0.185)$ (Figure 1) even though an increase in knowledge was present. However, the improved knowledge is presumably caused by respondents' access to information from their doctors, other health professionals, social media, or families instead of brief counseling-5A. This kind of access was beyond the control of the researchers.

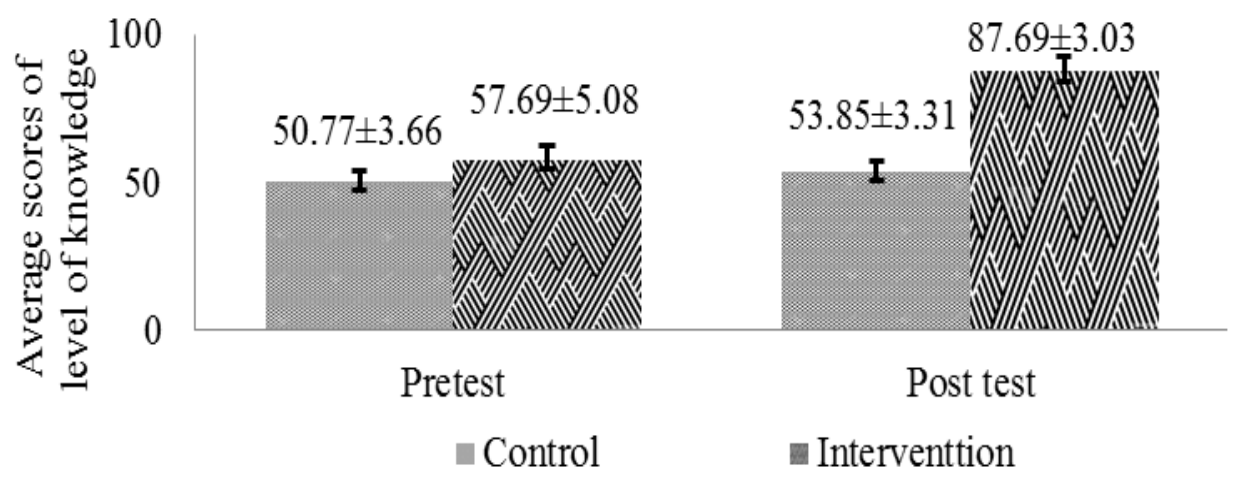

Figure 1. The mean pretest and posttest scores of knowledge of respondents who consume Fe fumarate at Jetis Community Health Center, Yogyakarta City

The mean scores of the control group in both pretest and posttest demonstrate a moderate level of knowledge with a final score of 50-75\% (Figure 1). Meanwhile, in the intervention group, there was an increase in the mean score, which represents sufficient knowledge among the respondents (final score $=765-100 \%$ ). Table IV shows that the majority of the intervention group has high knowledge of anemia and $\mathrm{Fe}$ fumarate intake (92.3\%) after receiving the brief counseling-5A, whereas the control group remains to have insufficient one. These results are consistent with previous studies, which correlate counseling by pharmacists with improved understanding and compliance with the consumption of iron supplements (Fitri, 2015; Anggreni, 2008; Heryadi et al., 2017).

Table IV shows that providing brief counseling-5A can increase respondents' knowledge (RR= 4.54 and $95 \%[\mathrm{CI}]=1.62-12.72$ ). In other terms, those who received it had a 4.54 times probability of experiencing increased knowledge higher than those who did not and exhibited clinically significant results with a 95\% confidence interval of 1.62-12.72. Respondents with good knowledge about anemia, Fe fumarate intake as an iron supplement, the management of its side effects, and nutritional balance during pregnancy are expected to influence changes in adherence to treatment and reduce the prevalence of anemia in pregnant women. 
Table IV. The descriptive analysis results of the pretest and posttest of respondents in their firstand second-trimester pregnancies who consume Fe fumarate at Jetis Community Health Center, Yogyakarta City

\begin{tabular}{|c|c|c|c|c|}
\hline \multirow{2}{*}{ Variables } & \multicolumn{2}{|c|}{ Respondents (n, \%) } & \multirow{2}{*}{$p$-value } & \multirow{2}{*}{$\begin{array}{c}\text { RR } \\
\text { (CI 95\%) }\end{array}$} \\
\hline & Intervention $(\mathrm{n}=13)$ & Control $(n=13)$ & & \\
\hline \multicolumn{5}{|l|}{ Knowledge } \\
\hline \multicolumn{5}{|l|}{ Pretest } \\
\hline Low & $3(23.1)$ & $4(30.8)$ & $0.343^{\mathrm{a}}$ & 4.54 \\
\hline Medium & $8(61.5)$ & $9(69.2)$ & & $(1.62-12.72)$ \\
\hline High & $2(15.4)$ & $0(00.0)$ & & \\
\hline \multicolumn{5}{|l|}{ Posttest } \\
\hline Low & $0(00.0)$ & $2(15.4)$ & $0.000^{\mathrm{a}^{*}}$ & \\
\hline Medium & $1(7.7)$ & $11(84.6)$ & & \\
\hline High & $12(92.3)$ & $0(0.00)$ & & \\
\hline \multicolumn{5}{|l|}{ Perceptions } \\
\hline \multicolumn{5}{|l|}{ Pretest } \\
\hline Negative & $9(69.2)$ & $7(53.8)$ & $0.420^{\mathrm{b}}$ & 4.54 \\
\hline Positive & $4(30.8)$ & $6(46.2)$ & & $(1.62-12.72)$ \\
\hline \multicolumn{5}{|l|}{ Posttest } \\
\hline Negative & $0(00.0)$ & $12(92.3)$ & $0.000^{\mathrm{b}^{*}}$ & \\
\hline Positive & $13(100.0)$ & $1(7.7)$ & & \\
\hline \multicolumn{5}{|l|}{ Compliance } \\
\hline \multicolumn{5}{|l|}{ Pretest } \\
\hline Non-compliant & $6(46.2)$ & $9(69.2)$ & $0.234^{\mathrm{a}}$ & 10.29 \\
\hline Less compliant & $7(53.8)$ & $4(30.8)$ & & $(1.56-67.99)$ \\
\hline Compliant & $0(00.0)$ & $0(00.0)$ & & \\
\hline \multicolumn{5}{|l|}{ Posttest } \\
\hline Non-compliant & $0(00.0)$ & $5(38.5)$ & $0.000^{\mathrm{b}^{*}}$ & \\
\hline Less compliant & $2(15.4)$ & $7(53.8)$ & & \\
\hline Compliant & $11(84.6)$ & $1(7.7)$ & & \\
\hline
\end{tabular}

${ }^{a}=$ Chi-square test to test the hypothesis of two unpaired categorical variables (table $2 \times 2$ ); ${ }^{b}=$ Mann-Whitney test to test the hypothesis of two unpaired categorical variables as an alternative to Chi-square test (table 2xk)); * marks a significant difference between the proportions of control and intervention groups $(p<0.050)$; $R R=$ relative risk to measure the relationship between independent and dependent variables in the $2 \times 2$ table analysis (cell merging, related to the presence or absence of change in the level of knowledge, perceptions, and compliance in the pretest and posttest)

\section{The effects of brief counseling-5A on the level of perceptions}

Perception is interpreted as the emotions or feelings of respondents toward the consumption of Fe fumarate as an iron supplement and anemia, as well as the risk of anemia during pregnancy. Perception defines whether the implemented therapy corresponds to patients' expectations and confidence in it, which further affect their willingness to make changes in their drug therapy or treatment strategies (Stegemann, 2016). The univariate analysis results indicated that all respondents in the control group had negative perceptions. Their posttest results were contrary to the ones in the intervention group who had positive attitudes of their health conditions and the consumption of iron supplements (100.0\%). The $\Delta$ score of perception is presented in detail in Table V. 
Table V. The $\Delta$ score of perceptions of respondents in their first- and second-trimester pregnancies who consume $\mathrm{Fe}$ fumarate at Jetis Community Health Center, Yogyakarta City before and after receiving brief counseling-5A

\begin{tabular}{lcc}
\multicolumn{1}{c}{ Groups } & $\Delta \pm \mathrm{SE}$ & $\boldsymbol{p}$-value between groups \\
\hline Control $(\mathrm{n}=13)$ & $-1.15 \pm 1.06$ & $0.000^{*}$ \\
Intervention & $7.00 \pm 1.26$ & \\
$(\mathrm{n}=13)$ & & \\
\hline
\end{tabular}

$\mathrm{SE}=\mathrm{Standard}$ Error $(\mathrm{SD} / \sqrt{\mathrm{n}}) ;{ }^{*}=$ the independent $\mathrm{t}$-test produces a significant difference $(p<0.050)$ in the mean $\Delta$ score between the control and intervention group

The $\Delta$ score of perceptions was analyzed by parametric independent t-test because the data in the control and intervention groups were normally distributed, with significance values (p) of 0.472 for the former and 0.999 for the latter. Table V presents a significant statistical difference in the mean $\Delta$ score of perceptions between the two groups $(\mathrm{p}=0.000)$. The intervention group has a higher $\Delta$ score than the control group. In the control group, the mean $\Delta$ score is marked with a decrease or, in other words, the posttest scores of several respondents are lower than in the pretest.

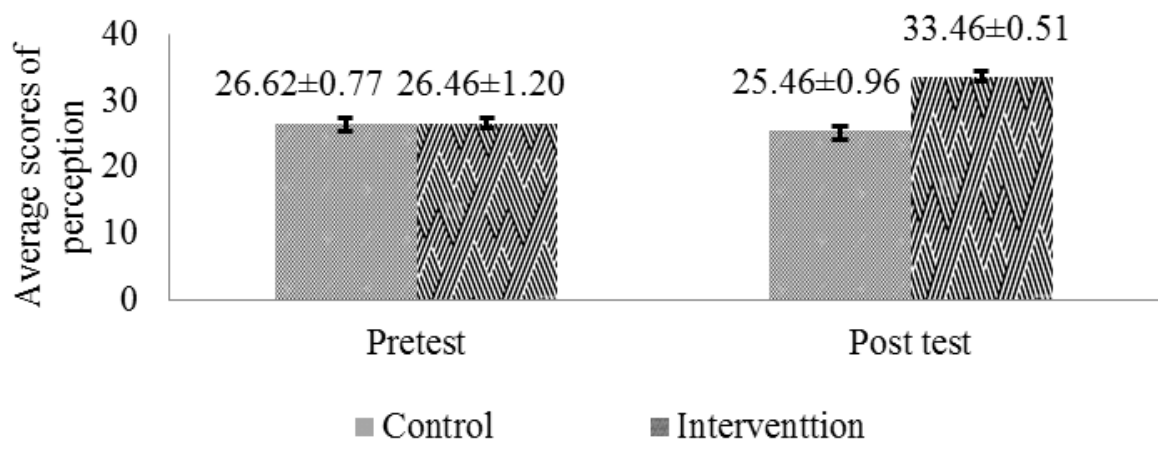

Figure 2. The mean pretest and posttest scores of perceptions of respondents who consume Fe fumarate at Jetis Community Health Center, Yogyakarta City

The $\Delta$ score of each research group is depicted in a graph (Figure 2). It indicates the absence of a significant difference between the mean pretest and posttest scores of the control group. The paired sample test resulted in p-values of 0.296 and 0.000 in the intervention group, which imply a significant difference between the mean pretest and posttest scores. In the control group, the mean scores showed no change and, therefore, the perceptions remained negative (final score $<28$ ). On the contrary, the respondents in the intervention group maintained to have positive perceptions. Positive attitudes of $\mathrm{Fe}$ fumarate consumption are attributable to the access of pregnant women to information provided by health services and reminder and motivation given by their families, which contribute to minimizing perceptions of probable adversities, including drug side effects (Rai et al., 2014; Nisar et al., 2014; Patience, 2016). With $\mathrm{RR}=4.54$ and $95 \%[\mathrm{CI}]=1.62-12.72$, the research found that respondents who received brief counseling-5A had a 4.54 times probability of experiencing improved perceptions higher than those who did not and showed clinically significant results with a $95 \%$ confidence interval of 1.62-12.72. As a conclusion, the modified brief counseling-5A delivered by pharmacists to the intervention group can change negative perception to positive opinions of anemia and the consumption of Fe fumarate as iron supplements during pregnancy. The theory of health belief model states that people's attitudes in health are determined by their perceptions of an illness (Lamorte, 2018). For this reason, a change in perception and, by extension, behavior can optimally achieve the objective of the therapy.

Pharmaciana Vol. 9, No. 2, Nov 2019, Page. 241 - 260 


\section{The effects of brief counseling-5A on the level of compliance}

In this study, compliance was measured with a questionnaire on adherence to the consumption of $\mathrm{Fe}$ fumarate and the fulfillment of nutritional intake during pregnancy, which consisted of 10 closeended questions or items. The univariate analysis of the posttest results proved that the respondents in the intervention group were generally compliant (88.4\%), while the ones in the control group were less compliant (53.8\%), as presented in Table VI.

Table VI. The $\Delta$ score of compliance of respondents in their first- and second-trimester pregnancies who consume Fe fumarate at Jetis Community Health Center, Yogyakarta City before and after receiving brief counseling-5A

\begin{tabular}{lrc}
\hline \multicolumn{1}{c}{ Groups } & \multicolumn{1}{c}{$\Delta \pm \mathrm{SE}$} & $\boldsymbol{p}$-value between groups \\
\hline Control $(\mathrm{n}=13)$ & $4.61 \pm 2.68$ & $0.000^{*}$ \\
Intervention $(\mathrm{n}=13)$ & $38.46 \pm 4.92$ & \\
\hline
\end{tabular}

$\mathrm{SE}=\mathrm{Standard}$ Error $(\mathrm{SD} / \sqrt{ } \mathrm{n}) ; *=$ the independent $\mathrm{t}$-test produces significant difference $(p<0.050)$ in the mean $\Delta$ score between the control and intervention group

The $\Delta$ score of compliance was analyzed using a parametric independent sample t-test because the data of the intervention and control groups were normally distributed ( $p>0.050)$. The results (Table VI) showed a significant increase in the mean $\Delta$ scores of compliance $(\mathrm{p}=0.000)$, as evident from the relatively high posttest scores during the follow-up phase on Day 31 . The paired sample t-test proved that the $\Delta$ score represented a significant difference of compliance in the intervention group before and after the brief-counseling-5A $(\mathrm{p}=0.000)$ but an insignificant one in the control group $(\mathrm{p}=0.111)$ (Figure 3). Some respondents in the control group showed an improvement in their compliance, as measured in the posttest, which was potentially caused by self-motivation, inducements given by their families, or information from health workers and social media, which were beyond the control of the researchers. The posttest scores of the control group were positive, but such improvement did not occur evenly throughout the respondents in this group.

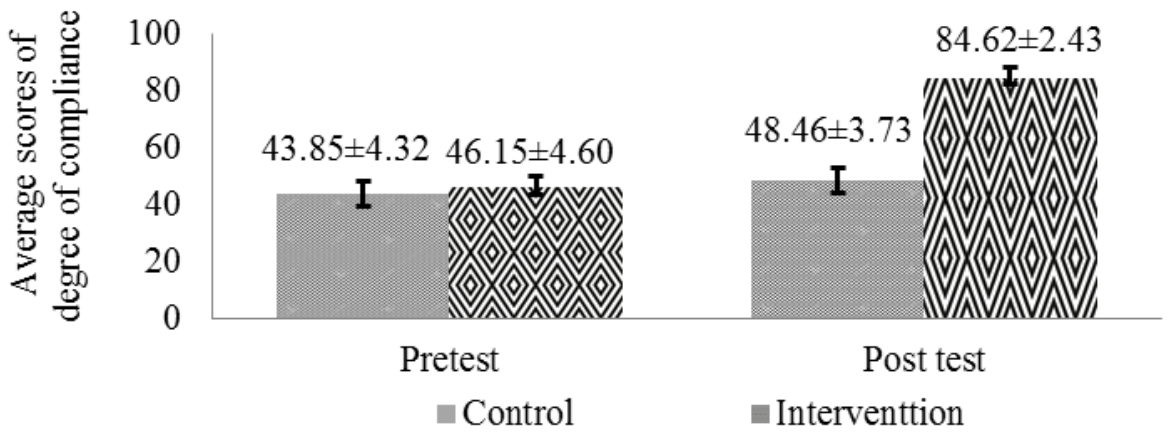

Figure 3. The mean pretest and posttest scores of compliances of respondents who consume $\mathrm{Fe}$ fumarate at Jetis Community Health Center, Yogyakarta City

The results are in line with several previous studies (Heryadi et al., 2017; Theng et al., 2017), which have confirmed that counseling by pharmacists can increase compliance with the consumption of iron supplements and reduce the prevalence of anemia in pregnant women. In contrast, another research in the City of Kiambu, Kenya with a sample size of 364 pregnant women affirms that only $40.9 \%$ of them have sufficient knowledge and good compliance (Kamau et al., 2019). It is believed to be caused by the absence of counseling on the consumption of iron supplements, limiting the access to complete information that focuses on proper administration and benefits of these supplements.

Based on the statistical analysis results, brief counseling-5A has played a part in improving the compliance of respondents in the observed hospital with the recommended consumption of $\mathrm{Fe}$ 
fumarate. The results showed $\mathrm{RR}=10.29$ with $95 \%[\mathrm{CI}]=1.56-67.99$ (Table IV). These figures mean that the respondents who received brief counseling-5A had a ten times probability of experiencing increased adherence higher than those who did not and showed clinically significant results with a 95\% confidence interval of 1.56-67.99.

As a conclusion, the level of knowledge, perceptions, and compliance has increased after the brief counseling-5A. In other words, the modification performed on brief counseling-5A and its provision to pregnant women at Jetis Community Health Center in Yogyakarta City can be used as a strategy to provide health education, raise awareness, and improve behavior and compliance with the prescribed consumption of iron supplements. Such behavior changes are expected to reduce the prevalence of anemia in pregnant women through increased adherence to the accurate and proper intake of iron supplements during pregnancy.

\section{Research Limitations}

Although this study has successfully correlated brief counseling-5A by pharmacists with the improved level of knowledge, perceptions, and compliance among pregnant women who consume $\mathrm{Fe}$ fumarate as iron supplements, its sample size does not represent the variety of age at pregnancy and hematological examination that identifies iron deficiency anemia. Future studies are recommended to involve a larger sample size that is representative of the targeted population (i.e., pregnant women at their first, second, and third trimester) with the same number of respondents in each research group. Also, hematological examination is required in the diagnosis of iron deficiency anemia, including the counts of hemoglobin $(\mathrm{Hb})$, hematocrit $(\mathrm{Hmt})$, red blood cell $(\mathrm{RBC})$, mean corpuscular hemoglobin $(\mathrm{MCH})$, mean corpuscular volume (MCV), mean corpuscular hemoglobin concentration (MCHC), serum iron, and total binding capacity (TIBC).

\section{CONCLUSIONS}

At Jetis Community Health Center, Yogyakarta City, the introduction of brief counseling with modified 5A module to first and second-trimester pregnant women who consume $\mathrm{Fe}$ fumarate as iron supplements can improve their knowledge, perception, and compliance with anemia management or prevention during pregnancy.

\section{ACKNOWLEDGMENTS}

Profound gratitude is extended to the Directorate of Research and Community Service under the Directorate General of Research and Technology Strengthening, and Development of the Ministry of Research, Technology, and Higher Education for their financial assistance through the 2019 postgraduate research scheme. Authors would like to thank the head of Jetis Community Health Center in Yogyakarta City, as well as the doctors, midwives, and pharmacists for their facilities and assistance during this research. Authors would also like to acknowledge all respondents for their willingness to participate in the study.

\section{REFERENCES}

Adam., 2015, Bloom's taxonomy of cognitive learning objectives, Journal of the Medical Library Association, 103(3): 152-53.

Adam., 2016, Anemia During Pregnancy, InTech Nutritional Deficiency, 112-24.

Akrom anda Nurwijayanti., 2015, Brief Counseling and Mobile Phone Short Message Service (SMS) Increase Patient Compliance, International Journal of Pharma Medicine and Biological Sciences, 4(3):171-174.

Anggreni., 2008, Kepatuhan Ibu Hamil dalam mengkonsumsi tablet zat besi terhadap tingkat kejadia anemia di Puskesmas Pekan Heran Kabupaten Indragiri Hulu, Sumatra Utara: University of Sumatera Utara Institutional Repository.

Azwar., 2012, Penyusunan Skala Psikologi, $2^{\text {nd }}$ edition, Yogyakarta: Pustaka Pelajar. 
Bloom., 1956, Taxonomy of Educational Objectives. Canada: David McKay Company, Inc.

Bosworth, Granger, Mendys, Brindis, Burkholder, Czajkowski, Granger., 2011, Medication adherence: a call for action, American Heart Journal, 162(3): 8.

Brookhart, Patrick, Schneeweiss, Avorn, Dormuth, Shrank, Canning., 2007, Physician follow-up and provider continuity are associated with long-term medication adherence, American Medical Association, 167: 848.

Endang and Fourianalisyawati., 2012, Komunikasi yang Relevan antara Dokter dan Pasien, Jurnal Psikogenesis, 1(1):82-87.

Fitri., 2015, Kepatuhan Konsumsi Suplemen Besi dan Pengaruhnya Terhadap Kejadian Anemia pada Ibu Hamil di Kota Tangerang, Master Thesis. Bogor: Program Pascasarjana Institut Pertanian Bogor.

Gebreamlak, Dadi and Atnafu., 2017, High Adherence to Iron/Folic Acid Supplementation during Pregnancy Time among Antenatal and Postnatal Care Attendant Mothers in Governmental Health Centers in Akaki Kality Sub City, Plos One Adherence and Associated Factors, 12(1):111.

Glasgow, Funnell, Bonomi, Davis, Beckham, and Wagner., 2002, Self-management aspects of the improving chronic illness care breakthrough series: implementation with diabetes and heart failure teams, Breakthrough Series Self-Management, 24(2): 80-87.

Heryadi, Sauriasari and Andrajati., 2017, The Influence of Pharmacist Counseling on Changes in Hemoglobin Levels of Pregnant Women at a Community Health Center in Indonesia. Asian Journal of Pharmceutical and Clinical Research, 10(5): 115-117.

Kamau, Kimani and Mirie., 2019, Counselling and knowledge on iron and folic acid supplementation (IFAS) among pregnant women in Kiambu County, Kenya: a cross-sectional study. AAS Open Research, 1(21): 1-5.

Kemenkes., 2012, Buku Saku Posyandu: Posyandu Menjaga Anak dan Ibu Tetap Sehat. Jakarta: Health Promotion Center Kementrian Kesehatan RI.

Kemenkes RI, 2014, Peraturan Meteri Kesehatan Republik Indonesia tentang Standar Tablet Tambah Darah bagi Wanita Usia subur dan Ibu Hamil. Jakarta: Kementrian Kesehatan RI.

Kemenkes., 2018. Hasil Utama Riskesdas, Riskesdas. Jakarta: Kementrian Kesehatan RI.

Lamorte, 2018, The Health Belief Model, Behavioral Change Models. Boston: Boston University School of Public Health.

Layqah., 2018, The practice of counseling in pharmacy: patients'perspectives, Journal of Analytical and Pharmaceutical Research, 7(4): 472-76.

Lutsey, Dawe, Villate and Valencia, 2008, Iron supplementation compliance among pregnant women in Bicol, Public Health Nutrition, 11(1): 76-82.

Mulianti, Akrom and Jatiningrum., 2014. Pengaruh brief counselling dan SMS terhadap tingkat perilaku adherensi, kepatuhan minum obat dan hasil terapi pasien diabetes melitus dengan hipertensi rawat jalan di poliklinik penyakit dalam RSUD Panembahan Senopati Bantul. Master Thesis. Yogyakarta: Faculty of Pharmacy, Ahmad Dahlan University.

Nisar, Alam, Aurangzeb and Dibley., 2014, Perceptions of antenatal iron-folic acid supplements in urban and rural Pakistan: a qualitative study, BMC Pregnancy and Childbirth, 14(344): 1-12.

Oriji, Enyindah and Nyeche., 2011, Factors determining compliance to routine iron supplementation in pregnancy at the University of Port Harcourt Teaching Hospital, Nigerian Journal of Medicine, 20(1): 131-134.

Patience, 2016, Knowledge and Perceptions of Risk of Anaemia During Pregnancy Among Pregnant Women in Ablekuma South. Dissertation. Ghana: School of Public Health College of Health Sciences University.

Patil, S., Khanwelkar, C., Patil, S., Thorat, V., Jadhav, S., Sontakke, A., 2013, Comparison of efficacy, tolerability, and cost of newer with conventional oral iron preparation. Al Ameen Journal Medical Sciences, 6(1), 29-33. 
Rai, Ratanasiri, Thapa and Koju., 2014, Effect of Knowledge and Perceptions on Adherence to Iron and Folate Supplementation during Pregnancy in Kathmandu, Nepal. Journal of Medical Association of Thailand, 97(10).

Rezk, Kandil, Dawood, Shaheen, and Allam, 2015, Oral lactoferrin versus ferrous sulphate and ferrous fumerate for the treatment of iron deficiency anemia during pregnancy, Journal of Advanced Nutrition and Human Metabolism, 740: 3-5.

Saputri, Akrom and Darmawan., 2017, Improving Outpatient's Quality of Life through Patient Adherence of Antihypertensive Therapy Using "Mobile Phone (SMS) and Brief Counseling$5 A "$ in Polyclinic of Internal Medicine at PKU Muhammadiyah Bantul Hospital, Yogyakarta, Indonesian Journal of Clinical Pharmacy, 6(2): 66-67.

Santiago, 2012, Ferrous versus ferric oral iron formulations for the treatment of iron deficiency: a clinical overview, The Scientific World Journal, 2-3.

Singhal, Kadian, Singh, and Ghalaut, 2015, Comparison of various oral iron salts in the treatment of iron deficiency anemia in pregnancy, Indian Journal of Obstetrics and Gynaecology Research, 2(3): $155-158$.

Stegemann, 2016, Developing drug products in an aging society: from concept to prescribing, AAPS Advances in the Pharmaceutical Sciences Serial 24, USA: American Association of Pharmaceutical Scientists.

Theng, Zakaria and Yusof, 2017, Knowledge and Attitude on Consumption of Iron Supplement Among Pregnant Women in Kuala Terengganu, Terengganu, Malaysian Applied Biology, 46(3): $105-12$.

Thirukkanesh and Zahara, 2010, Compliance to Vitamin and Mineral Supplementation among Pregnant Women in Urban and Rural Areas in Malaysia, Pakistan Journal of Nutrition, 9(8): 744-750.

Vaske, Hammitt, Uysal, and Sirakaya-Turk., 2017, Research Methods for Leisure, Recreation and Tourism, 2ed, Colorado State University: CAB International.

Vernissa, Andrajati, and Supardi, 2017, The Effectiveness of leaflet and counseling methods on iron tablet consumption adherence and haemoglobin status among pregnant women with anemia in Primary Health Care in Bogor District, Media Litbangkes, 27(4): 232-234.

Whitlock, Orleans, Pender and Allan, 2002, Evaluating primary care behavioral counseling interventions: an evidence-based approach, American Journal Preventive of Medicine, 22(4): 67-84.

WHO, 2011, Haemoglobin Concentrations for The Diagnosis of Anaemia and Assessment of Severity. Geneva: World Health Organization World Health Organization. 